\title{
BUDAYA POLITIK DALAM MASYARAKAT PRAGMATIS
}

\author{
Sumartono \\ Dosen Komunikasi FISIPOL \\ Universitas Ekasakti Padang \\ Email: rajoameh1999@yahoo.com
}

\begin{abstract}
ARTICLE INFO ABSTRACT
General elections and regional head elections in Indonesia are conducted directly. The pattern of community participation is changed. The emergence of pragmatism or political pragmatism in society becomes an interesting political culture to study. Practically, pragmatism means a condition that encourages people to get benefits instantly. As a result, people take any actions to make it happen. In reality, pragmatism not only affects the upper classes (those with a high level of education)

Keywords: political culture, political reality, pragmatic society but also ordinary people (lower class society or those with low levels of political education). The development of money politics, cow trade politics, the sale of votes, or the existence of political dowry is a sign that there has been a political transaction becoming one of the indicators of pragmatism reality in society.
\end{abstract}

\section{Pendahuluan}

Secara aplikatif, budaya politik merupakan pola perilaku suatu masyarakat dalam kehidupan bernegara, penyelenggaraan administrasi negara, politik pemerintahan, hukum, adat istiadat, dan norma kebiasaan yang dihayati oleh seluruh anggota masyarakat setiap harinya. Budaya politik juga dapat diartikan sebagai suatu sistem nilai bersama suatu masyarakat yang memiliki kesadaran untuk berpartisipasi dalam pengambilan keputusan kolektif dan penentuan kebijakan publik untuk masyarakat seluruhnya.

Budaya politik merupakan bagian dari kebudayaan masyarakat dengan ciri-ciri yang lebih khas. Istilah budaya politik meliputi masalah legitimasi, pengaturan kekuasaan, proses pembuatan kebijakan pemerintah, kegiatan partai-partai politik, perilaku aparat negara, serta gejolak masyarakat terhadap kekuasaan yang memerintah. Budaya politik merupakan sistem nilai dan keyakinan yang dimiliki bersama oleh masyarakat. Namun, setiap unsur masyarakat berbeda pula budaya politiknya, seperti antara masyarakat umum dengan para elitenya. Seperti juga di Indonesia, menurut Benedict Anderson, kebudayaan Indonesia cenderung membagi secara tajam antara kelompok elite dengan kelompok massa.

Kajian tentang budaya politik selalu menarik. Selain berkaitan dengan perkembangan politik di suatu negara, budaya politik juga berhubungan dengan dinamika partisipasi politik masyarakat. Artinya, perkembangan politik dalam suatu negara sangat dipengaruhi oleh perkembangan budaya yang ada dalam masyarakat negara tersebut. Pendidikan dan pemahaman politik masyarakat (dalam konteks Indonesia) sangat memengaruhi perkembangan budaya politik di Indonesia yang memiliki karakteristik berbeda pada masa Orde Lama, Orde Baru, dan Reformasi. Perkembangan budaya politik diwujudkan dengan terciptanya partai-partai politik. Partai politik selalu berusaha untuk merebut simpati rakyat dalam kegiatan pemilu yang bertujuan untuk menempatkan orang-orang partainya dalam pemerintahan yang tidak bertentangan dengan ideologi negara dan UUD 1945. Agar masyarakat memiliki pandangan politik yang sesuai, sosialisasi politik dilakukan sesuai dengan kondisi dan perkembangan lingkungan yang ada. Semakin stabil pemerintahan, semakin mudah untuk melakukan sosialisasi politik. Pada prinsipnya, tidak ada perubahan yang sempurna tetapi kita harus berusaha agar perkembangan budaya politik terjadi sesuai dengan yang diharapkan dan mencapai kepentingan bersama, sehingga masyarakat yang memegang peranan penting dalam perkembangan budaya politik suatu negara mampu berpartisipasi dalam kehidupan politik. 
Berdasarkan pemahaman teoritikal, kita memahami bahwa budaya terbentuk dari sebuah kebiasaan yang dilakukan oleh masyarakat secara terus menerus. Demikian halnya dengan kebiasaan yang ingin serba praktis dan instan, cepat serta mudah dalam menyelesaikan dan memenuhi segala sesuatu kebutuhan. Kebiasaan tersebut berubah menjadi sebuah budaya pragmatis atau instan.

Budaya serba praktis dan instan di Indonesia kini telah menjadi kebudayaan secara nasional, tidak hanya berjalan di suatu wilayah atau daerah tertentu, namun di seluruh Indonesia. Masyarakat Indonesia cenderung menggemari sesuatu yang bersifat praktis, dimana masyarakat selalu mementingkan segi kepraktisan dalam memenuhi kebutuhannya. Masyarakat lebih memilih sesuatu yang dapat diperoleh secara praktis dan instan, dimana tidak merepotkan masyarakat ketika membutuhkan sesuatu. Contohny, mulai dari jenis makanan, pelayanan, mencapai sesuatu, pemenuhan kebutuhan, sampai di hampir seluruh aspek kehidupan (termasuk politik) sudah dilingkupi oleh budaya serba instan.

Mendiskursuskan tentang budaya politik menjadi menarik ketika dikaitkan dengan konteks kekinian di dalam masyarakat. Kecendrungan munculnya sikap pragmatis dalam kehidupan politik menjadi sinyalemen bahwa realitas politik tidak hanya bicara merebut dan mempertahankan kekuasaan tetapi bagaimana budaya politik yang berkembang di masyarakat disikapi dengan cara pragmatis.

\section{Apa itu budaya politik ?}

Almond dan Verba (dalam Alfian dan Sjamsuddin, 1991 : 21) mendefinisikan budaya politik sebagai suatu sikap orientasi yang khas warga negara terhadap sistem politik dan aneka ragam bagiannya, dan sikap terhadap peranan warga negara yang ada di dalam sistem tersebut. Dengan kata lain, bagaimana distribusi pola-pola orientasi khusus menuju tujuan politik di antara masyarakat bangsa itu. Lebih jauh mereka menyatakan, bahwa warga negara senantiasa mengidentifikasikan diri mereka dengan simbol-simbol dan lembaga kenegaraan berdasarkan orientasi yang mereka miliki. Dengan orientasi itu pula mereka menilai serta mempertanyakan tempat dan peranan mereka di dalam sistem politik.

Berikut ini adalah beberapa pengertian budaya politik (yang dapat dijadikan sebagai pedoman: (1). Budaya politik adalah aspek politik dari nilai-nilai yang terdiri atas pengetahuan, adat istiadat, tahayul, dan mitos. Semuanya dikenal dan diakui oleh sebagian besar masyarakat. Budaya politik memberikan pemahaman rasional untuk menolak atau menerima nilai-nilai dan norma lain, (2). Budaya politik dapat dilihat dari aspek doktrin dan aspek generiknya. Yang pertama menekankan pada isi atau materi, seperti sosialisme, demokrasi, atau nasionalisme. Yang kedua (aspek generik) menganalisa bentuk, peranan, dan ciri-ciri budaya politik, seperti militan, utopis, terbuka, atau tertutup, (3). Hakikat dan ciri budaya politik yang menyangkut masalah nilai-nilai adalah prinsip dasar yang melandasi suatu pandangan hidup yang berhubungan dengan masalah tujuan, dan (4). Bentuk budaya politik menyangkut sikap dan norma, yaitu sikap terbuka dan tertutup, tingkat militansi seseorang terhadap orang lain dalam pergaulan masyarakat. Pola kepemimpinan (konformitas atau mendorong inisiatif kebebasan), sikap terhadap mobilitas (mempertahankan status quo atau mendorong mobilitas), prioritas kebijakan (menekankan ekonomi atau politik).

Dari pengertian budaya politik yang telah diuraikan, nampaknya membawa kita pada suatu pemahaman konsep yang memadukan dua tingkat orientasi politik, yaitu sistem dan individu. Dengan orientasi yang bersifat individual ini, tidaklah berarti bahwa dalam memandang sistem politiknya kita menganggap masyarakat akan cenderung bergerak ke arah individualisme. Jauh dari anggapan yang demikian, pandangan ini melihat aspek individu dalam orientasi politik hanya sebagai pengakuan akan adanya fenomena dalam masyarakat secara keseluruhan tidak dapat melepaskan diri dari orientasi individual.

Menurut Ranney (dalam Ryass, 2000 : 64), terdapat dua komponen utama dari budaya politik, yaitu orientasi kognitif (cognitive orientations) dan orientasi afektif (affective oreintatations). Sementara itu, Almond dan Verba dengan lebih komprehensif mengacu pada apa yang dirumuskan Parsons dan Shils tentang klasifikasi tipe-tipe orientasi, bahwa budaya politik mengandung tiga komponen obyek politik sebagai berikut: (1). Orientasi kognitif : yaitu berupa pengetahuan tentang dan kepercayaan pada politik, peranan dan segala kewajibannya serta input dan outputnya, (2). Orientasi afektif : yaitu perasaan terhadap sistem politik, peranannya, para aktor dan pe-nampilannya, dan (3). Orientasi evaluatif : yaitu keputusan dan pendapat tentang obyek-obyek politik yang secara tipikal melibatkan standar nilai dan kriteria dengan informasi dan perasaan. 


\section{Tipe-Tipe Budaya Politik}

Berkaitan dengan tipe-tipe budaya politik, Gabriel A Almond (dalam Effendi, 1991 : 27) membagi atas budaya politik parokial, budaya politik kaula (subjek), dan budaya politik partisipan.

3.1. Budaya politik parokial yaitu budaya politik yang tingkat partisipasi politiknya sangat rendah. Budaya politik suatu masyarakat dapat dikatakan Parokial apabila frekuensi orientasi mereka terhadap empat dimensi penentu budaya politik mendekati nol atau tidak memiliki perhatian sama sekali terhadap keempat dimensi tersebut. Tipe budaya politik ini umumnya terdapat pada masyarakat suku Afrika atau masyarakat pedalaman di Indonesia. dalam masyarakat ini tidak ada peran politik yang bersifat khusus. Kepala suku, kepala kampung, kyai, atau dukun,yang biasanya merangkum semua peran yang ada, baik peran yang bersifat politis, ekonomis atau religius.

3.2. Budaya politik kaula (subjek),yaitu budaya politik masyarakat yang sudah relatif maju baik sosial maupun ekonominya tetapi masih bersifat pasif. Budaya politik suatu masyarakat dapat dikatakan subyek jika terdapat frekuensi orientasi yang tinggi terhadap pengetahuan sistem politik secara umum dan objek output atau terdapat pemahaman mengenai penguatan kebijakan yang dibuat oleh pemerintah. Namun, frekuensi orientasi mengenai struktur dan peranan dalam pembuatan kebijakan yang dilakukan pemerintah tidak terlalu diperhatikan. Para subyek menyadari akan otoritas pemerintah dan secara efektif mereka diarahkan pada otoritas tersebut. Sikap masyarakat terhadap sistem politik yang ada ditunjukkan melalui rasa bangga atau malah rasa tidak suka. Intinya, dalam kebudayaan politik subyek, sudah ada pengetahuan yang memadai tentang sistem politik secara umum serta proses penguatan kebijakan yang di buat oleh pemerintah.

3.3. Budaya politik partisipan yaitu budaya politik yang ditandai dengan kesadaran politik yang sangat tinggi. Masyarakat mampu memberikan opininya dan aktif dalam kegiatan politik. Budaya politik juga merupakan suatu bentuk budaya politik yang anggota masyarakatnya sudah memiliki pemahaman yang baik mengenai empat dimensi penentu budaya politik. Mereka memiliki pengetahuan yang memadai mengenai sistem politik secara umum, tentang peran pemerintah dalam membuat kebijakan beserta penguatan, dan berpartisipasi aktif dalam proses politik yang berlangsung. Masyarakat cenderung di arahkan pada peran pribadi yang aktif dalam semua dimensi di atas, meskipun perasaan dan evaluasi mereka terhadap peran tersebut bisa saja bersifat menerima atau menolak.

\section{Pragmatisme Politik}

Pragmatisme berasal dari bahasa Yunani pragma berarti perbuatan (action) atau tindakan (practice). Isme berarti ajaran, aliran, paham. Dengan demikian, pragmatisme berarti ajaran/aliran/paham yang menekankan bahwa pemikiran itu mengikuti tindakan. Dalam Kamus Besar Bahasa Indonesia, pragmatisme berarti kepercayaan bahwa kebenaraan atau nilai suatu ajaran (paham/doktrin/gagasan/pernyataan/dsb) bergantung pada penerapannya bagi kepentingan manusia. Sedangkan pragmatis berarti bersifat praktis dan berguna bagi umum; bersifat mengutamakan segi kepraktisan dan kegunaan (kemanfaatan); mengenai/bersangkutan dengan nilai-nilai praktis. Karena itu, pragmatisme memandang bahwa kriteria kebenaran ajaran adalah faedah atau manfaat. Suatu teori atau hipotesis dianggap oleh pragmatisme benar jika membawa suatu hasil. Dengan kata lain, suatu teori itu benar jika berfungsi. Jadi, pragmatisme dapat dikategorikan ke dalam pembahasan mengenai teori kebenaran.

Kebenaran, menurut James dalam bukunya, The Meaning of Truth, adalah sesuatu yang terjadi pada ide, yang sifatnya tidak pasti. Sebelum seseorang menemukan satu teori berfungsi maka tidak diketahui kebenaran teori itu. Kebenaran akan selalu berubah sejalan dengan perkembangan pengalaman. Sesuatu yang dikatakan benar dapat dikoreksi oleh pengalaman berikutnya. Oleh karena itu, paham pragmatisme tidak mengenal adanya kebenaran mutlak. Kebenaran ditentukan oleh kemanfaatan.

Ide pragmatisme keliru dari tiga sisi. Pertama, pragmatisme mencampuradukkan kriteria kebenaran ide dan kegunaan praktisnya. Kebenaran ide adalah suatu hal, sedangkan kegunaan praktis ide itu adalah hal lain. Kebenaran sebuah ide diukur dengan kesesuaian ide itu dengan realita atau dengan standar-standar yang dibangun di atas ide dasar yang sudah diketahui kesesuaiannya dengan realita. Kegunaan praktis suatu ide untuk memenuhi hajat manusia tidak diukur dari keberhasilan penerapan ide itu sendiri. Jadi, kegunaan praktis ide tidak mengandung implikasi kebenaran ide, tetapi hanya menunjukkan fakta terpuaskannya kebutuhan manusia. Kedua, pragmatisme menafikan peran 
akal manusia. Menetapkan kebenaran sebuah ide adalah aktivitas intelektual dengan menggunakan standar-standar tertentu. Penetapan kepuasan manusia dalam pemenuhan kebutuhannya adalah identifikasi naluriah. Identifikasi naluriah dapat menjadi ukuran kepuasan manusia dalam memuaskan hajatnya, tetapi tidak dapat menjadi ukuran kebenaran sebuah ide. Artinya, pragmatisme telah menafikan aktivitas intektual dan menggantinya dengan identifikasi naluriah. Dengan kata lain, pragmatisme telah menundukkan keputusan akal pada kesimpulan yang dihasilkan dari identifikasi naluriah. Ketiga, pragmatisme menimbulkan relativitas dan kenisbian kebenaran sesuai dengan perubahan subyek penilai ide --baik individu, kelompok, maupun masyarakat-- serta perubahan konteks waktu dan tempat. Dengan kata lain, kebenaran hakiki pragmatisme baru dapat dibuktikan -menurut pragmatisme itu sendiri-- setelah melalui pengujian kepada seluruh manusia dalam seluruh waktu dan tempat. Ini jelas mustahil dan tidak akan pernah terjadi. Pragmatisme berarti telah menjelaskan inkonsistensi internal yang dikandungnya dan menafikan dirinya sendiri.

\section{Budaya Politik Dan Masyarakat Pragmatis Di Indonesia}

Bila kita telaah lebih jauh lagi, maka kita dapat menggambarkan budaya politik di Indonesia saat ini sebagai berikut: (1). Konfigurasi subkultur di Indonesia masih aneka ragam, walaupun tidak sekompleks yang dihadapi oleh India misalnya, yang menghadapi masalah perbedaan bahasa, agama, kelas, kasta yang semuanya relatif masih rawan/rentan, (2). Budaya politik Indonesia yang bersifat Parokial-kaula di satu pihak dan budaya politik partisipan di lain pihak, di satu sisi masih ketinggalan dalam mempergunakan hak dan dalam memikul tanggung jawab politiknya yang mungkin di sebabkan oleh isolasi dari kebudayaan luar, pengaruh penjajahan, feodalisme, bapakisme, dan ikatan primordial. Sikap ikatan primordial yang masih kuat berakar, yang dikenal melalui indikatornya berupa sentimen kedaerahan, kesukaan, keagamaan, perbedaan pendekatan terhadap keagamaan tertentu; puritanisme dan non puritanisme dan lain-lain. Kecendrungan budaya politik Indonesia yang masih bersifat paternalisme dan patrimonial, hal ini masih tercermin dengan berkembangnya fenomena bapakisme atau sikap asal bapak senang, dan (3). Dilema interaksi tentang introduksi modernisasi (dengan segala konsekuensinya) dengan pola-pola yang telah lama berakar sebagai tradisi dalam masyarakat.

Selain ketiga hal gambaran budaya politik di tanah air, kita juga dapat mendeskripsikan realitas budaya politik masyarakat: (1). Hirarki yang tegar/ketat. Masyarakat Jawa, dan sebagian besar masyarakat lain di Indonesia, pada dasarnya bersifat hirarkis. Stratifikasi sosial yang hirarkis ini tampak dari adanya pemilahan tegas antara penguasa dengan rakyat kebanyakan (wong cilik). Masingmasing terpisah melalui tatanan hirarkis yang sangat ketat. Alam pikiran dan tatacara sopan santun diekspresikan sedemikian rupa sesuai dengan asal usul kelas masing-masing. Penguasa dapat menggunakan bahasa 'kasar' kepada rakyat kebanyakan. Sebaliknya, rakyat harus mengekspresikan diri kepada penguasa dalam bahasa 'halus'. Dalam kehidupan politik, pengaruh stratifikasi sosial semacam itu antara lain tercemin pada cara penguasa memandang diri dan rakyatnya, (2). Kecendrungan Patronage. Pola hubungan Patronage merupakan salah satu budaya politik yang menonjol di Indonesia. Pola hubungan ini bersifat individual. Dalam kehidupan politik, tumbuhnya budaya politik semacam ini tampak misalnya di kalangan pelaku politik. Mereka lebih memilih mencari dukungan dari atas daripada menggali dukungn dari basisnya, dan (3). Kecendrungan Neopatrimonisalistik. Salah satu kecendrungan dalam kehidupan politik di Indonesia adalah adanya kecendrungan munculnya budaya politik yang bersifat neo-patrimonisalistik; artinya meskipun memiliki atribut yang bersifat modern dan rasionalistik seperti birokrasi, perilaku negara masih memperlihatkan tradisi dan budaya politik yang berkarakter patrimonial.

Laswell telah menanamkan pengertian yang paling pragmatis atas politik, siapa dapat apa, kapan, dan bagaimana. Apa yang dilontarkannya itu sangat mudah dipahami, bahwa memang demikianlah politik. Akar konfrontasi, dari kacamata Laswell, terjadi ketika definisi tersebut diterapkan dan mengundang ketidakpuasan dari para pelaku kunci politik. Pengertian "mendapatkan sesuatu", bukan berarti yang bersifat fisik, seperti uang atau materi lain, tetapi, tentu juga yang nonmaterial, seperti ideologi, kedudukan, harga diri, dan gengsi. Di dalam "mendapatkan sesuatu", semua kekuatan politik saling bersaing di dalam suatu arena permainan politik.

"All my games," Kata Indira Gandhi, Perdana Menteri perempuan India pada masanya. Politisi mestinya sadar, sejak awal politik adalah juga merupakan suatu permainan, tak sekadar adu ketangkasan, tetapi lebih dari itu adalah adu kekuatan. Pendekatannya, bisa secara keras (dominatif) 
atau sebaliknya lembut (soft) atau hegemonik. Dalam menyerang dan bertahan secara politik, politisi bisa bergaya seperti apakah Mohammad Ali ataukah Mike Tyson dalam bertinju.

Politik tidak semata-mata identik dengan adu kekuatan. Politik juga banyak dibahas dari sudut pandang filsafatnya. Dari Aristoteles, misalnya, kita mengenal ungkapan zoon politicon, manusia pada dasarnya merupakan "seekor binatang politik". Namun, Aristoteles tidak berpandangan negatif pada politik, justru ia mendefinisikannya sebagai usaha yang ditempuh warga negara untuk mewujudkan kebaikan bersama.

Salah satu kebijakan pemerintah untuk mewujudkan kebaikan bersama adalah pelaksanaan pemilu langsung, yang pertama kali dilaksanakan masa kepemimpinan Presiden Megawati Soekarno Putri yang digelar "Orde Gotong Royong". Pemilu langsung merupakan sejarah baru dalam perpolitikan Indonesia dan terutama bagi para pemilih. Pasalnya, baru pertama kali dilaksanakan dalam sistem pelaksanaan yang berbeda dengan sistem Pemilu-Pemilu sebelumnya. Yang selanjutnya pelaksanaan pemilihan langsung untuk memilih pemimpin dilanjutkan pada pemilihan gubernur, wali kota dan bupati karena sebelumnya gubernur, walikota dan bupati terpilih dengan sistem perwakilan yang lebih banyak kelemahan dari pada kelebihannya, misalnya adanya politik dagang sapi dan politik uang, pemimpin terpilih tidak memiliki legitimasi yang kuat karena kriterianya tidak sesuai dengan keinginan masyarakat, pemimpin terpilih "berhutang budi" pada partai politik sehingga sistem check and balance antara legislatif dan eksekutif tidak terjaga.

J.J.Rousseau mengungkapkan bahwa demokrasi dengan sistem perwakilan, bukanlah demokrasi sebenarnya, karena keinginan para wakil rakyat (Will of the few) bukanlah keinginan rakyat. Peringatan Rousseau semakin memperkuat posisi suara rakyat yang selama ini lebih banyak dijadikan sebagai pelengkap penderita.

Sejak tahun 2005 ketika pilkada langsung pertama kali dilakukan sampai sekarang, puluhan kepala daerah (gubernur, wali kota, bupati) telah menjadi terpidana kasus korupsi. Melihat fenomena ini, tidak mengherankan jika menghitung ongkos politik yang harus dikeluarkan pasangan calon kepala daerah menjadi sangat tinggi. Selain harus membayar mahar kepada partai politik yang mengusung dalam pilkada, mereka juga harus "mengamankan suara" dan "mengamankan kemenangan" dengan segala cara. Mantan Menteri Dalam Negeri Gamawan Fauzi pernah mengatakan bahwa besarnya jumlah dana yang harus dikeluarkan seseorang untuk menjadi kepala daerah (bupati/wali kota sekitar Rp 5 miliar, gubernur sekitar Rp 20 miliar). Dana sebesar itu agak mustahil dapat diperoleh kembali dari gaji yang diterima, bahkan selama lima tahun karena Gaji bupati Rp 6,2 juta, sementara gubernur Rp 8,7 juta.

Masyarakat memandang Pilkada adalah sebagai sebuah proyek yang sangat menguntungkan tanpa berpikir bagaimana kualitas dari proses dan hasil pilkada, sehingga yang terjadi saat ini masyarakat kita sudah menjadi "mata duitan". Namun, dengan melihat berbagai fenomena dalam pelaksanaan pilkada di daerah tidak berarti sistem pemilihan harus dikembalikan ke sistem perwakilan karena hal itu bukan solusi yang terbaik dan membuat kita semakin mundur. Descartes pada saat melakukan rekonstruksi filsafat, langkah pertama yang dia lakukan secara teoritis adalah membuang sikap skeptis. Yang dilakukan, ia mencari air mancur yang lebih alami dari prinsip-prinsip sejati, dan menemukannya dalam pikiran manusia; Kesadaran diri untuk mendapatkan kebenaran dasar, dan untuk memutuskan apa yang menyenangkan.

Mencermati pergeseran perilaku politik seseorang atau kelompok yang "suka duit" dapat dilihat pada dua model analisis teori tentang perilaku pemilih, yang selama ini berkembang di Indonesia. Pertama, Geertz yang melihat pola perilaku politik dengan orientasi sosio-religius santri dan abangan. Kedua, model Jackson yang melihat faktor pola hubungan antara pemimpin dan pengikut dalam perilaku politik.

Dengan demikian, tingkah laku politik tidak berdiri sendiri tetapi terkait dengan faktor-faktor lain yang melekat dalam suatu sistem politik. Ada empat faktor atau variabel yang berpengaruh. Pertama, kekuasaan yakni cara untuk mencapai hal yang diinginkan antara lain melalui sumbersumber di antara kelompok-kelompok dalam masyarakat itu. Kedua, kelompok yakni tujuan-tujuan dikejar oleh perilaku-perilaku atau kelompok politik. Ketiga, kebijakan yakni hasil dari interaksi antara kekuasaan dan kepentingan yang biasanya dalam bentuk perundang-undangan. Keempat budaya politik yakni orientasi subjektif dari individu terhadap sistem politik.

Terjadinya pergeseran dalam perilaku pemilih yang "suka duit" tidak semata-mata karena persoalan pada sistem pemilihannya tetapi banyak faktor yang harus dibenahi terutama bagaimana 
memperbaki kualitas pendidikan politik masyarakat yang merupakan akar dari permasalahan tersebut. Oleh sebab itu yang paling bertanggungjawab dalam hal tersebut adalah para pakar politik, lembaga-lembaga masyarakat yang berfokus pada polling pendapat, partai-partai politik, organisasi masyarakat dan pihak pemerintah. Mereka harus lebih intensif dalam menyosialisasikan tema "Berpolitik Yang Beretika" apakah dalam bentuk seminar, panel diskusi, simposium, dialog interaktif di TV, dan kegiatan-kegiatan lain yang disponsori oleh pemerintah, agar nantinya masyarakat punya bahan-bahan masukan yang nantinya dapat dijadikan referensi dalam berdiskusi diantara mereka dan bukan lagi didasari oleh rasa dendam dari prilaku-prilaku pemimpin sebelumnya dan saat ini, jadi semuanya didasarkan atas pertimbangan yang ilmiah dan asas manfaat.

Merujuk pada realitas yang ada, budaya politik yang berkembang pada era reformasi ini adalah budaya politik yang lebih berorientasi pada kekuasaan yang berkembang di kalangan elit politik. Budaya seperti itu telah membuat struktur politik demokrasi tidak dapat berjalan dengan baik. Walaupun struktur dan fungsi-fungsi sistem politik Indonesia mengalami perubahan dari era yang satu ke era selanjutnya, namun tidak pada budaya politiknya.

Menurut Karl D. Jackson (1978 : 23), budaya Jawa telah mempunyai peran yang cukup besar dalam mempengaruhi budaya politik yang berkembang di Indonesia. Relasi antara pemimpin dan pengikutnya pun menciptakan pola hubungan patron-klien (bercorak patrimonial). Kekuatan orientasi individu yang berkembang untuk meraih kekuasaan dibandingkan sebagai pelayan publik di kalangan elit merupakan salah satu pengaruh budaya politik Jawa yang kuat.

Menurut penelitian yang dilakukan oleh Agus Dwiyanto dkk (2002: 71) mengenai kinerja birokrasi di beberapa daerah, bahwa birokrasi publik masih mempersepsikan dirinya sebagai penguasa daripada sebagai abdi yang bersedia melayani masyarakat dengan baik. Hal ini dapat dilihat dari perilaku para pejabat dan elit politik yang lebih memperjuangkan kepentingan kelompoknya dibandingkan dengan kepentingan rakyat secara keseluruhan.

Dengan menguatnya budaya paternalistik, masyarakat lebih cenderung mengejar status dibandingkan dengan kemakmuran. Reformasi pada tahun1998 telah memberikan sumbangan bagi berkembangnya budaya poltik partisipan, namun kuatnya budaya politik patrimonial dan otoriterianisme politik yang masih berkembang di kalangan elit politik dan penyelenggara pemerintahan masih senantiasa mengiringi. Walaupun rakyat mulai peduli dengan input-input politik, akan tetapi tidak diimbangi dengan para elit politik karena mereka masih memiliki mentalitas budaya politik sebelumnya. Sehingga budaya politik yang berkembang cenderung merupakan budaya politik subjek-partisipan.

Dalam pandangan Ignas Kleden, terdapat lima preposisi tentang perubahan politik dan budaya politik yang berlangsung sejak reformasi 1998, antara lain: (1). Orientasi Terhadap kekuasaan, Misalnya saja dalam partai politik, orientasi pengejaran kekuasaan yang sangat kuat dalam partai politik telah membuat partai-partai politik era reformasi lebih bersifat pragmatis, (2). Politik mikro vs politik makro, Politik Indonesia sebagian besar lebih berkutat pada politik mikro yang terbatas pada hubungan-hubungan antara aktor-aktor politik, yang terbatas pada tukar-menukar kepentingan politik. Sedangkan pada politik makro tidak terlalu diperhatikan dimana merupakan tempat terjadinya tukarmenukar kekuatan-kekuatan sosial seperti negara, masyarakat, struktur politik, sistem hukum, civil society, dan sebagainya, (3). Kepentingan negara vs kepentingan masyarakat, Realitas politik lebih berorientasi pada kepentingan negara dibandingkan kepentingan masyarakat, dan (4). Desentralisasi politik, Pada kenyataannya yang terjadi bukanlah desentralisasi politik, melainkan lebih pada berpindahnya sentralisme politik dari pemerintah pusat ke pemerintah daerah. Dengan demikian, budaya politik era reformasi tetap masih bercorak patrimonial, berorientasi pada kekuasaan dan kekayaan, bersifat sangat paternalistik, dan pragmatis. Hal ini menurut Soetandyo Wignjosoebroto karena adopsi sistem politik hanya menyentuh pada dimensi struktur dan fungsi-fungsi politiknya, namun tidak pada budaya politik yang melingkupi pendirian sistem politik tersebut.

\section{Simpulan}

Budaya politik dalam masyarakat pragmatis telah menjadi realitas politik yang patut dicermati. Aktivitas politik yang membutuhkan partisipasi masyarakat seakan mengalami benturan manakala masyarakatnya bersifat pragmatis. Pola perilaku serba instan jelas mempengaruhi perilaku politik baik di tingkat elit maupun masyarakat umumnya. Kemurnian dukungan dan lahirnya 
pemimpin yang memiliki kepekaan sosial jelas sulit menjadi kenyataan manakala sindrom pragmatis telah menjangkiti masyarakat secara keseluruhan.

\section{Daftar Pustaka}

1) Alfian. (1986). Masalah dan Prospek Pembangunan Politik di Indonesia, Jakarta : PT. Gramedia Pustaka Utama.

2) ------. (1991). Komunikasi Politik dan Sistem Politik Indonesia, Jakarta : PT. Gramedia Pustaka Utama.

3) Alfian dan Nazaruddin Sjamsuddin (ed.), (1991). Profil Budaya Politik Indonesia, Jakarta: PT Pustaka Utama Grafiti.

4) Almond, Gabriel dan Sidney Verba, (1999). Budaya Politik, Tingkah Laku Politik dan Demokrasi di Lima Negara, Penerjemah (Sahat Simamora), Jakarta : Bumi Aksara.

5) Budiardjo, Miriam. (2008). Dasar-Dasar Ilmu Politik, Jakarta : PT. Gramedia Pustaka Utama.

6) Cangara, Hafied. (2007). Pengantar Ilmu Komunikasi, Jakarta : Raja Grafindo Persada.

7) --- (2011). Komunikasi Politik, Konsep, Teori, dan Strategi, Jakarta : Rajawali Pers.

8) Dwiyanto, Agus, dkk, (2002). Reformasi Birokrasi Publik Di Indonesia, Yogyakarta : Pusat Studi Kependudukan dan Kebijakan Yogyakarta.

9) Effendy, Onong Uchjana. (2003). Ilmu, Teori, dan Filsafat Komunikasi. Bandung : Citra Aditya Bakti.

10) Jackson, Karl D, 1978. The Political Implications of Structure and Culture in Indonesia, California : University of California.

11) McNair, Brian. (2011). An Introduction to Political Communication, USA : Routledge.

12) Nimmo, Dan. (1982). Komunikasi Politik. Bandung : Remaja Rosda Karya.

13) Pabottinggi, Mochtar. (1993). Komunikasi Politik dan Transformasi Ilmu Politik, Jakarta : Gramedia Pustaka Utama.

14) Rauf, Maswadi. (1993). Indonesia dan Komunikasi Politik, Jakarta : Gramedia Pustaka Utama.

15) Ryass, Muhammad, 2000. Makna Pemerintahan Tinjauan dari Segi Etika dan Kepemimpinan, Jakarta : PT Mutiara Sumber Widya.

16) Siregar, Amir Efendi (ed.), 1991. Arus Pemikiran Ekonomi Politik : Esai-Esai Terpilih, Yogyakarta: Tiara Wacana.

17) Surbakti, Ramlan. (2007). Memahami Ilmu Politik, Jakarta : PT Grasindo.

18) T. May Rudy. (2003). Pengantar Ilmu Politik, Wawasan Pemikiran dan Kegunaannya, Bandung : PT Refika Aditama.

19) Toha, Miftah. (2007). Birokrasi dan Politik di Indonesia, Jakarta : PT Raja Grafindo Persada. 